\title{
INFLUENCE OF HIGH-VOLTAGE TRANSMISSION LINES ON POLLUTANT CONCENTRATION IN NONURBANIZED AREAS
}

\author{
V. Valuntaitė and R. Girgždienè \\ Vilnius Gediminas Technical University, Sauletekio 11, LT-10223 Vilnius, Lithuania \\ E-mail: vaida.valuntaite@fm.vgtu.lt
}

Received 11 September 2008; revised 18 November 2008; accepted 4 December 2008

\begin{abstract}
The variations of ozone and aerosol particles as possible pollutants in the vicinity of high-voltage transmission lines are presented and discussed. The ozone, aerosol particle $(D>0.4 \mu \mathrm{m})$ number concentrations and meteorological parameters near two high-voltage $330 \mathrm{kV}$ transmission lines and at the "background" site at the $220 \mathrm{~m}$ distance from the lines were investigated. During the investigation period the average ozone concentration close to high-voltage lines was higher than the "background" concentration and the instantaneous ozone concentration level was higher by $38 \%$ in separate cases, especially during the nighttime. The influence of meteorological parameters on the ozone concentration variation is discussed and it is determined that the relative humidity, wind speed and direction were the most important parameters causing the ozone concentration increase in the surroundings of transmission lines in nonurbanized areas. The analysis of aerosol particle number concentration data showed that the high-voltage lines were not the source of aerosol particles in the area of the experiment.
\end{abstract}

Keywords: high-voltage transmission lines, ozone, aerosol particles, concentration, meteorological parameters

PACS: $92.60 . \mathrm{Sz}, 52.80 . \mathrm{Hc}, 92.60 . \mathrm{Mt}$

\section{Introduction}

Industrialization, the population growth, and the rapid development in technology have all resulted in enormous human impact on the environment. Most of the pollutants are emitted from densely populated urban medium into the atmosphere and the exposure possibility to urban air pollutants is relatively high $[1,2]$. However, contaminants can also form in locations with lower population density if the anthropogenic sources of their emission exist there.

Ozone, through its respiratory irritation, is well recognized as a significant problem in urban areas of Europe, where the EPA standard for ambient ozone concentration is often exceeded. Ozone in polluted areas mostly forms as a result of reactions between photochemically reactive hydrocarbons and oxides of nitrogen under the influence of sunlight $[3,4]$. Ozone is naturally existing admixture of the atmosphere in the boundary layer, but technogenic sources also exist, which influence the increase of the ozone level. A large amount of ozone can be produced during the corona discharge. Such a natural source of ozone is lightning and the corona discharge during thunderstorm events. One of the anthropogenic sources of various pollutants is high-voltage transmission lines (HVLs). Intensive electric and magnetic fields form in the vicinity of highvoltage lines. The effect of such lines exceeding $300 \mathrm{kV}$ is detected at a distance of approximately $200 \mathrm{~m}$ from them [5]. The noise level near the high-voltage lines reaches 50-55 dBA, i.e. it considerably exceeds the normal background (30-40 dBA) in surrounding rural areas. High-voltage lines can emit dangerous electromagnetic waves over a distance up to $400 \mathrm{~m}$. The research carried out in UK and Europe has shown that all power lines were surrounded by a corona of electrically charged ions. The greater corona was found near the older lines. Ions from the corona were carried downwind of the lines, attaching themselves to up to 15000 particles $/ \mathrm{m}^{3}$ floating past in the air [6].

It was shown [7] that the high-voltage lines can also be a significant source of ozone. The corona discharge near HVLs leads to the atomic oxygen formation. Oxygen atoms are highly reactive, and they quickly react with oxygen molecules to form ozone:

$$
\mathrm{O}\left({ }^{3} \mathrm{P}\right)+\mathrm{O}_{2}+\mathrm{M} \rightarrow \mathrm{O}_{3}+\mathrm{M} .
$$

Moreover, the HVLs can generate active radicals, such as $\mathrm{OH}$, and thus can promote oxidation of volatile organic compounds (VOCs) and change the air composition in their vicinity. 
In Lithuania the hourly ozone concentration in ambient air varies in a wide range, from 2 to $110 \mathrm{ppb}$. Longterm investigation showed that during $9 \%$ of measurement time it exceeded $50 \mathrm{ppb}$ [8].

Meteorological conditions affect the formation, transport, deposition, and seasonal behaviour of ozone [9]. The factors favouring the formation of ozone are the intensive solar radiation, low wind speed, high temperature, and restricted boundary layer depth. Radiation and temperature drive the chemical reaction producing ozone, while boundary layer characteristics and the absence of wind are the factors which lead to the build-up of precursors and limit dispersion $[10,11]$.

Enhanced ozone concentrations, as a rule, affect adversely the biota and human health, destroy the lacquer coating and other materials [12-14]. Ozone disturbs breathing, reduces resistance of an organism to infectious diseases, causes poisonings, headaches, and general lassitude [15]. The toxicity of ozone is especially increased in the presence of nitrogen oxides, sulphur dioxide, and some other substances. The mutagenic effect is also possible because ozone evokes the same changes in live organisms as the ionizing radiation. It is established that the effect of ozone and aerosol particles on human nostrils, throat, and eyes is much stronger compared to the effect of each contaminant separately [16].

The aim of the work was to investigate the peculiarities of the change in pollutant concentration, to determine the ozone distribution near high-voltage transmission lines, and to ascertain the influence of meteorological parameters on the ozone concentration variation.

\section{Location of the experiment and methodology}

The experiment was carried out near Utena in the Juškenai village $\left(55^{\circ} 33^{\prime} \mathrm{N}, 25^{\circ} 39^{\prime} \mathrm{E}\right)$ in Aukštaitija region in the eastern part of Lithuania on 22-27 September 2007. Field investigations were carried out near two high-voltage transmission lines of $330 \mathrm{kV}$ (Fig. 1) and at the $220 \mathrm{~m}$ distance from the lines. The ozone concentration measured at this distance was regarded as the "background" concentration. The high-voltage transmission lines run from east to west. The ozone concentration data from the Rūgšteliškis environmental monitoring station were also used for comparison with data obtained at the experiment site. The Rūgšteliškis station $\left(55^{\circ} 26^{\prime} \mathrm{N}, 26^{\circ} 04^{\prime} \mathrm{E}\right)$ is situated about $25 \mathrm{~km}$ northeastward from Juškẻnai village. Ozone concentration near high-voltage lines was measured with the RS1003 ozone analyzer and the "background" ozone concentra-

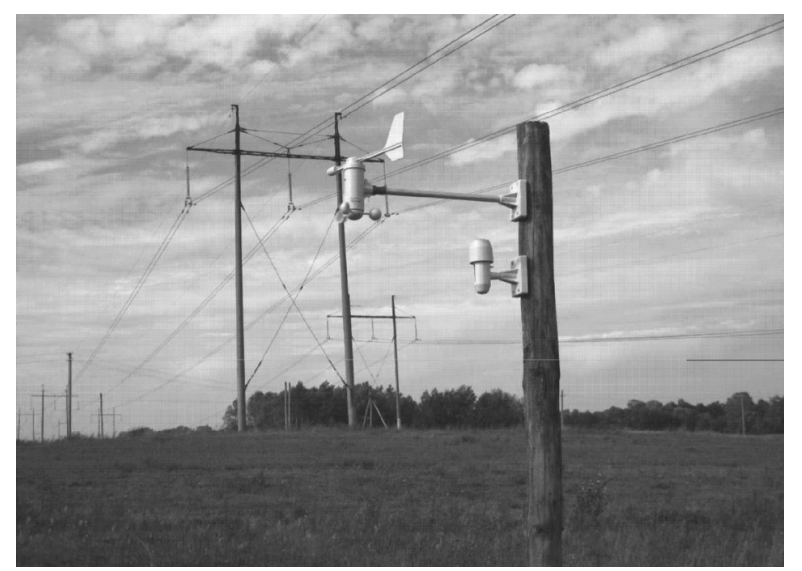

Fig. 1. High-voltage transmission lines with devices for measurement of meteorological parameters.

tion was measured with the ML 9811 analyzer. Operation of these analyzers is based on the principle of UV absorption. The ozone measurement range was 0 $500 \mathrm{ppb}$. The sensitivity of these instruments is $0.5 \mathrm{ppb}$, the noise level is less than $0.05 \mathrm{ppb}$, and the zero drift is less than $1 \mathrm{ppb} / 7$ days. Both analyzers were calibrated before the experiment and after calibration they operated simultaneously for some days by sucking air from the same tube. The obtained results showed very good agreement between measurement values; the linear correlation coefficient was 0.997 at the $99 \%$ confidence level. Ozone concentrations were measured continuously and the averaged values were recorded every 10 seconds. The aerosol particle counter AZ-5 was used for the continuous measurement of the number concentration of aerosol particles $(D>0.4 \mu \mathrm{m})$.

The main meteorological parameters were measured during the experiment. The air temperature, relative humidity, wind speed and direction were measured with the PC Radio Weather Station, and the data were stored into the computer automatically. The meteorological parameters were measured at the $1.5 \mathrm{~m}$ height. The device measures the air temperature $\left(-30\right.$ to $\left.+70^{\circ} \mathrm{C}\right)$ with the accuracy of $\pm 1^{\circ} \mathrm{C}$. The wind speed in the interval of $0-60 \mathrm{~m} / \mathrm{s}$ is measured with the accuracy of $\pm 0.3 \mathrm{~m} / \mathrm{s}$ and the wind direction resolution is 5 degrees. The entire wind direction data set was 3 minute averages and it was divided into eight sectors: north-west (NW), north $(\mathrm{N})$, north-east (NE), east (E), south-east (SE), south (S), south-west (SW), and west (W), which represent the angles $292.5^{\circ}-337.5^{\circ}, 337.5^{\circ}-22.5^{\circ}, 22.5^{\circ}-67.5^{\circ}$, $67.5^{\circ}-112.5^{\circ}, 112.5^{\circ}-157.5^{\circ}, 157.5^{\circ}-202.5^{\circ}, 202.5^{\circ}-$ $247.5^{\circ}$, and $247.5^{\circ}-292.5^{\circ}$, respectively.

Ozone concentration measurements across the highvoltage transmission lines were performed by using a moving platform with the ozone analyzer and computer 
on it. The carriage moved with steady speed across the lines $60 \mathrm{~m}$ to one side and $140 \mathrm{~m}$ to the other side and the ozone concentration was fixed every 10 metres. Teflon tubes were used for the air sample sucking at the $1.5 \mathrm{~m}$ height above the ground surface.

The air mass transport backward trajectory analysis was applied to the identification of the air mass origin. The data were taken from the National Oceanic and Atmospheric Administration webpage www.arl.noaa.gov/ ready.html.

\section{Results}

The changes of the ozone and other pollutant concentrations are closely related to the meteorological conditions in the investigation region and the origin of air masses that are moving over this area. During the experiment the air mass transport changed their direction several times. The air mass transport from southwestern direction was observed on 22 September. The transport direction changed to western at 5 a.m. of 23 September and at 1 p.m. it turned to north-western. From 4 p.m. of 24 September air masses were transported from south-east till the end of the experiment. Thus, the air mass transport from the south-east predominated during the whole experiment.

The variations of main measured parameters during the experiment are provided in Fig. 2: the ozone concentration near the high-voltage lines and a "background" concentration, the difference between these concentrations, number concentration of aerosol particles, the wind speed and direction.

The concentration of ozone near the high-voltage transmission lines was mostly higher compared to the "background" concentration at a distance of $220 \mathrm{~m}$ (near a residential house) during the experiment. The difference between these ozone concentrations varied from minus $17 \mathrm{ppb}$ to plus $13 \mathrm{ppb}$. The obtained ozone data were compared to the data from the Rūgšteliškis station (Fig. 3) to estimate whether the ozone concentration is higher at the site of the experiment. Unfortunately, the ozone data for 22-24 September at the Rūgšteliškis station were not available, therefore only the comparison of 3-day data was made. The average ozone concentration during this period near the highvoltage transmission lines was $32 \mathrm{ppb}$ and at the monitoring station it was only $17 \mathrm{ppb}$. The results show that the ozone concentration close to the high-voltage lines was constantly higher. The comparable results were obtained [7] near 220 and $500 \mathrm{kV}$ HVLs: the ozone concentration was higher than the "background" ozone level by 6.2 and $8.45 \%$, respectively. It proves that high-voltage transmission lines can affect the level of ozone in their close vicinity. It should be noted that the ozone changes and levels during the daytime were similar at both sites near the high-voltage transmission lines and at the background monitoring station. The maximum difference between half-hour ozone concentrations was up to $23 \%$. This difference was higher, up to $72 \%$, during the night-time when the ozone level due to very weak wind (Fig. 2) was caused by other local conditions, and one of them can be an additional ozone source. Furthermore, it indicates the influence of highvoltage lines at the $220 \mathrm{~m}$ distance from $330 \mathrm{kV}$ lines, i. e. the increase of the ozone concentration is recorded.

The number concentration of aerosol particles $(D>$ $0.4 \mu \mathrm{m}$ ) close to the high-voltage transmission lines varied in the range of $(10-100) \times 10^{6}$ particles $/ \mathrm{m}^{3}$ (Fig. 2) during the field investigation. Data analysis showed that the high-voltage transmission lines were not the local source of these aerosol particles or it was a very small one, and it was impossible to assess its influence during this experiment. Variation of the aerosol particle concentration was influenced by the change of air mass transport, the direction of which mostly coincided with the wind direction [17]. As mentioned above, the direction of air mass transport changed several times during the experiment. In case of the stable transport of air masses from south-eastern regions, the number concentration of aerosol particles changed insignificantly and no diurnal variation was observed. The number concentration of aerosol particles changed together with the change of the air mass transport direction. The comparative analysis was carried out according to the assumption that the number and mass concentrations of aerosol particles correlate [18]. Using the predicted data of hourly PM10 (particulate matter with diameter $\leq 10 \mu \mathrm{m}$ ) [19], it was obvious that the mass concentration of aerosol particles at the site of the experiment on 22 September should increase and reach $100 \mu \mathrm{g} / \mathrm{m}^{3}$, and it should decrease to $35-50 \mu \mathrm{g} / \mathrm{m}^{3}$ from $2 \mathrm{p} . \mathrm{m}$. on 23 September. The mass concentration of PM10 fluctuated in the range of $20-50 \mu \mathrm{g} / \mathrm{m}^{3}$ on 24 September. The PM10 mass concentration dropped to $25-50 \mu \mathrm{g} / \mathrm{m}^{3}$ from 11 p.m. on 25 of September and it was only $10-20 \mu \mathrm{g} / \mathrm{m}^{3}$ during the night-time. The steady mass concentration of PM10 of $10-20 \mu \mathrm{g} / \mathrm{m}^{3}$ was recorded on 26-27 September. Comparison of aerosol number concentration data obtained during the experiment with the PM10 mass concentration has shown that the linear correlation coefficient is $0.85, \alpha=0.95$. This confirms that the number concentration of aerosol par- 


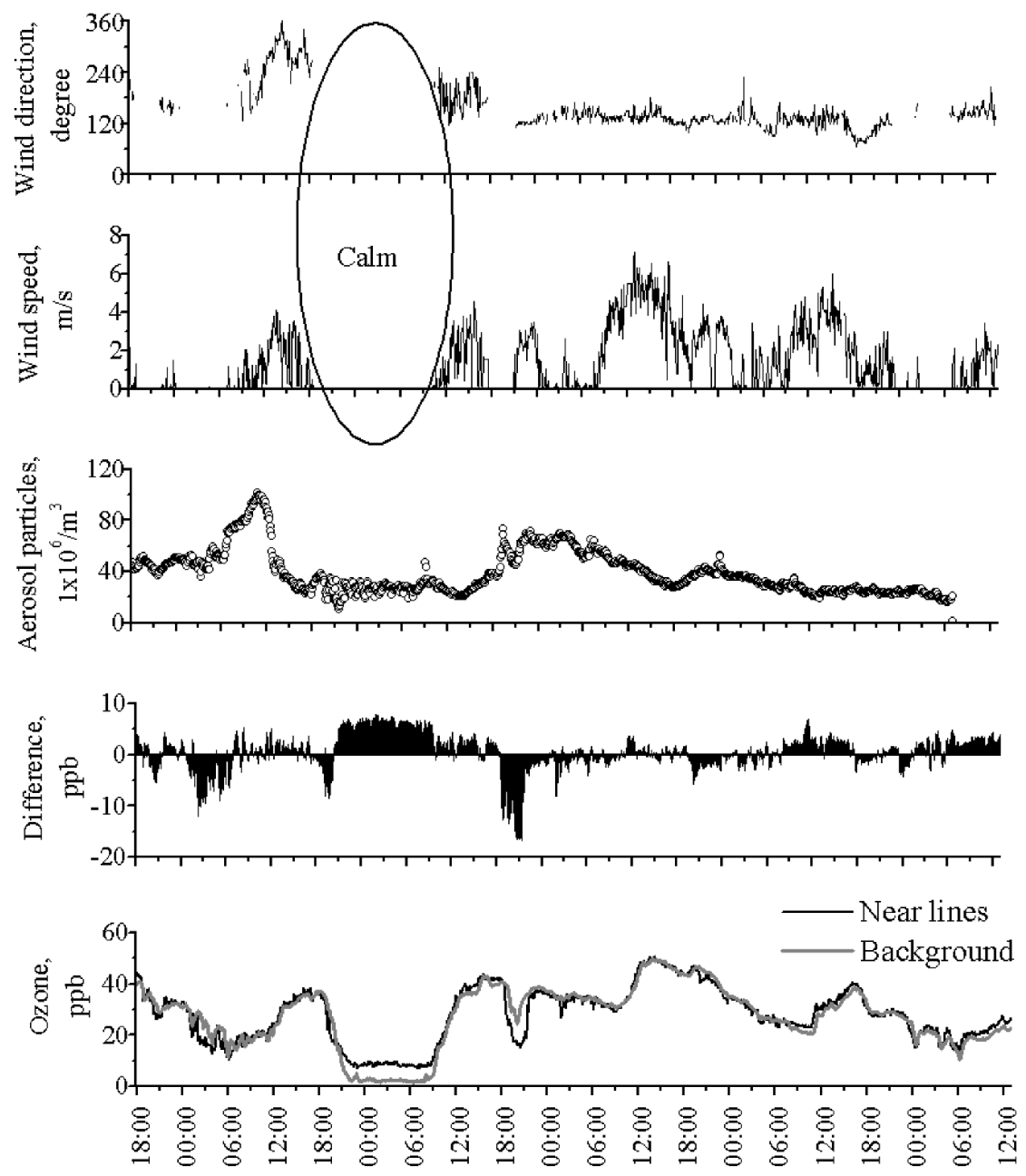

Time, h

Fig. 2. Variation of the main parameters during the experiment on 22-27 September 2007.

ticles changes together with the change of the PM10 mass concentration during the experiment. Therefore, the correlation of the aerosol particle number concentration with the PM10 mass concentration and with the air mass transport direction allow us to state that the main source of aerosol particles $(D>0.4 \mu \mathrm{m})$ was not the high-voltage transmission lines.

As the difference between ozone concentrations at different measurement sites (close to the high-voltage transmission lines and near the residential house) was not constant during the experiment (Fig. 2), the relationship between this difference and meteorological parameters was investigated.

The corona effect occurs when electricity discharges into the ambient atmosphere from a high-voltage source. Its intensity increases under conditions of heavy rain and high humidity (in general $>80 \%$ ) [20]. Under wet and humid conditions, water drops accumulate on the conductors of transmission lines and thereby increase the corona activity. The natural production rate of ozone is inversely proportional to humidity. Therefore, humidity is the same factor increasing corona discharges from transmission lines and blocking the production of ozone. Under high relative humidity conditions, mostly at night-time, two counteractions are observed: the production and destruction of ozone.

Relative humidity varied from 43 to $100 \%$ during the experiment period. The highest humidity was observed during the first two nights, when its value was $100 \%$ for a long time. The most noticeable differences between the ozone level (from -17 up to $+13 \mathrm{ppb}$ ) were recorded just at this time. The interval of relative humidity was narrow from 25 September when it varied from 43 to $76 \%$ and the difference between ozone values was only between -6 and $+7 \mathrm{ppb}$.

Air temperature and relative humidity variations in the atmosphere are very closely related. Air temperature varied in the range of $2-23{ }^{\circ} \mathrm{C}$ during the experi- 
ment. The lowest temperature was detected during the night-time from 23 to 24 September when relative humidity was $100 \%$. Long-lasting calm conditions were recorded and air temperature dropped to $+2{ }^{\circ} \mathrm{C}$ on this night and the measured difference between the ozone concentrations was most substantial for the whole research period. The narrow interval of air temperature change was recorded on 25-27 September when temperature did not drop below $9{ }^{\circ} \mathrm{C}$ at night and did not exceed $21^{\circ} \mathrm{C}$ in the daytime. The weather without rainfall dominated during the experiment: not intensive rainfalls were detected only at 1 p.m. on 22 September (max. intensity $2.6 \mathrm{~mm} / \mathrm{h}$ ) and at $1 \mathrm{p} . \mathrm{m}$. on 26 September (max. intensity $0.5 \mathrm{~mm} / \mathrm{h}$ ).

The wind speed and direction were not stable during the experiment, especially during the first days of measurement (Fig. 2). Weak winds dominated during the experiment, and the speed of $5 \mathrm{~m} / \mathrm{s}$ was recorded only during $3 \%$ of the measurement time. Not only long-lasting calm conditions prevailed during the experiment (marked as calm in ellipse in Fig. 2), but the wind speed was also near $0 \mathrm{~m} / \mathrm{s}$ during a lot of short episodes. Calm conditions covered about $38 \%$ of the time. South-eastern wind dominated during the remaining time $(61 \%)$ of measurement. The wind direction along the lines was recorded relatively rarely: the eastern direction was observed during $9 \%$ and the western direction during $5 \%$ of the measurement time, respectively.

If high-voltage lines are the additional source of ozone, the difference between ozone concentrations should depend on the direction of wind; therefore, the relationship between the wind direction and ozone concentration difference was analysed.

Analysis revealed (Fig. 4) that almost during all the time the average difference was positive, i. e. the ozone concentration near the lines was higher. The higher ozone concentration near the house was detected when north-eastern and eastern winds dominated. The cases of the NE-N-NW direction wind were few, therefore data were insufficient for the reliable analysis. Lower concentrations close to the lines were also obtained when the wind direction was from the east. It should be noted that wind of this direction was recorded mostly in the evenings or early mornings. It was impossible to find the cause of this phenomenon, probably due to a short duration of the experiment. The highest average difference between ozone concentrations was detected when the wind blew from the SW direction. The maximum ozone concentration of $34 \mathrm{ppb}$ near the HVLs was detected at the wind of the SE direction; how-

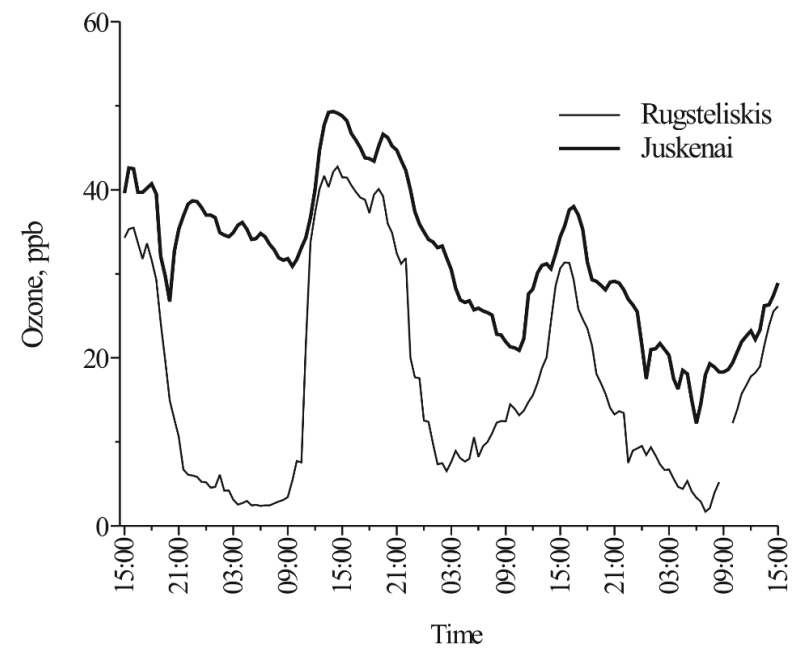

Fig. 3. Variation of ozone concentrations at the site of the experiment and at Rūgšteliškis monitoring station on 24-27 September 2007.

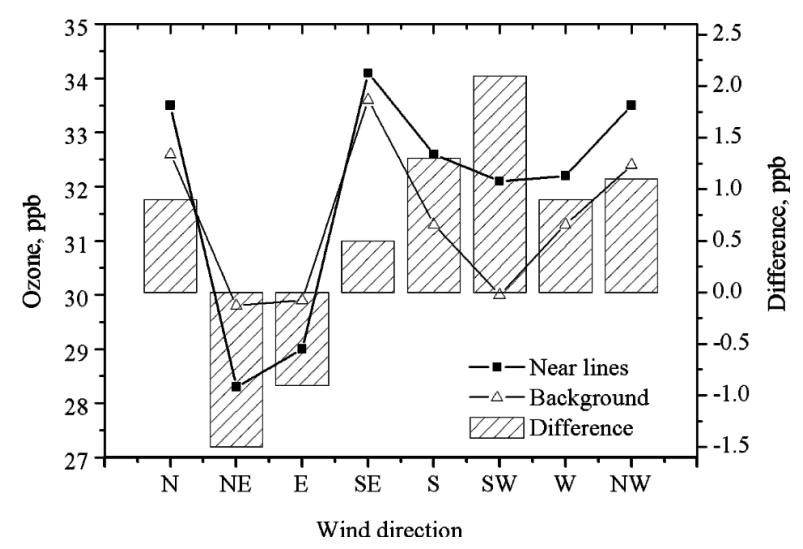

Fig. 4. Relationship between the wind direction and average ozone concentrations and their differences.

ever, the difference between ozone concentrations was minimal. The wind of the south-eastern direction was recorded at any time of the day during the experiment. It was observed that the wind was stronger when it was blowing from the south-eastern direction (average speed $2.4 \mathrm{~m} / \mathrm{s}$ ), whereas the obtained experiment results showed that higher ozone concentrations were observed when a stronger wind was blowing.

Because the relationship between the ozone concentration and wind direction was determined, the further analysis was performed to find out how the ozone concentration changes when wind is blowing across and along transmission lines. The winds blowing along the high-voltage transmission lines dominated only between 9 a.m. and 6 p.m. during the experiment and were not observed at any other time. The instantaneous difference between ozone concentrations at the wind blowing along lines varied from -8 to $+8 \mathrm{ppb}$. 


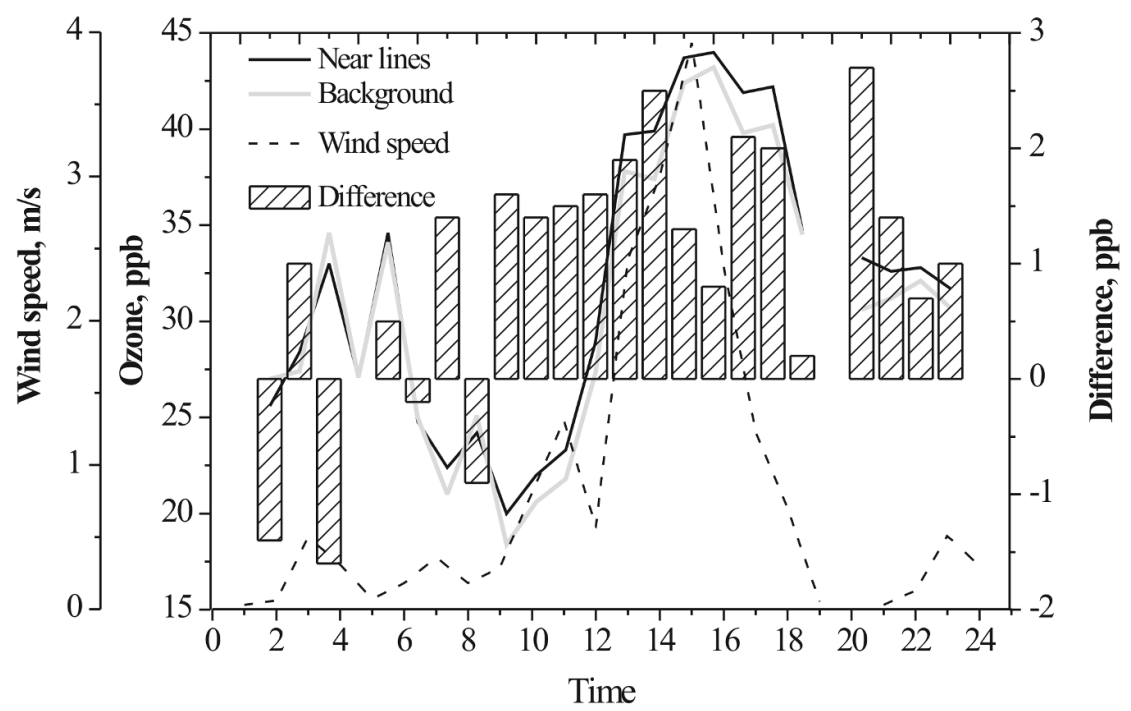

Fig. 5. Distribution of average ozone concentrations, their difference, and wind speed during a day when wind was blowing across the HVLs (wind of southern direction).

The concentration was practically always higher near the lines when such wind direction was dominant.

When the wind direction was across the HVLs, the difference between ozone concentrations was variable: sometimes higher short-term ozone concentrations were observed near the lines, sometimes at a "background" site. The average difference varied between -2 and +3 ppb (Fig. 5). The wind blowing across lines was not detected only at 8 p.m.

The ozone concentration field is distributed not equally between lines and in their vicinity. The data obtained by measuring the ozone concentration across HVLs showed that depending on the wind speed and direction a few mini fields with the maximal ozone concentration can be observed. The ozone concentration increase near HVLs was up to $38 \%$ in comparison with the concentration at a "background" site during separate measurements. By using the Kriging interpolation method of Surfer software, the typical ozone concentration field is presented in Fig. 6, when the SE wind direction prevailing during the experiment with speed lower than $2 \mathrm{~m} / \mathrm{s}$ has been observed. The data revealed that under such meteorological conditions the ozone concentration near the HVLs increased up to $44 \mathrm{ppb}$. The ozone "background" concentration varied in the interval of 30.1$1.9 \mathrm{ppb}$.

\section{Conclusions}

1. The experiment results have shown that high-voltage transmission lines are the additional significant ozone sources in nonurbanized territories. Their

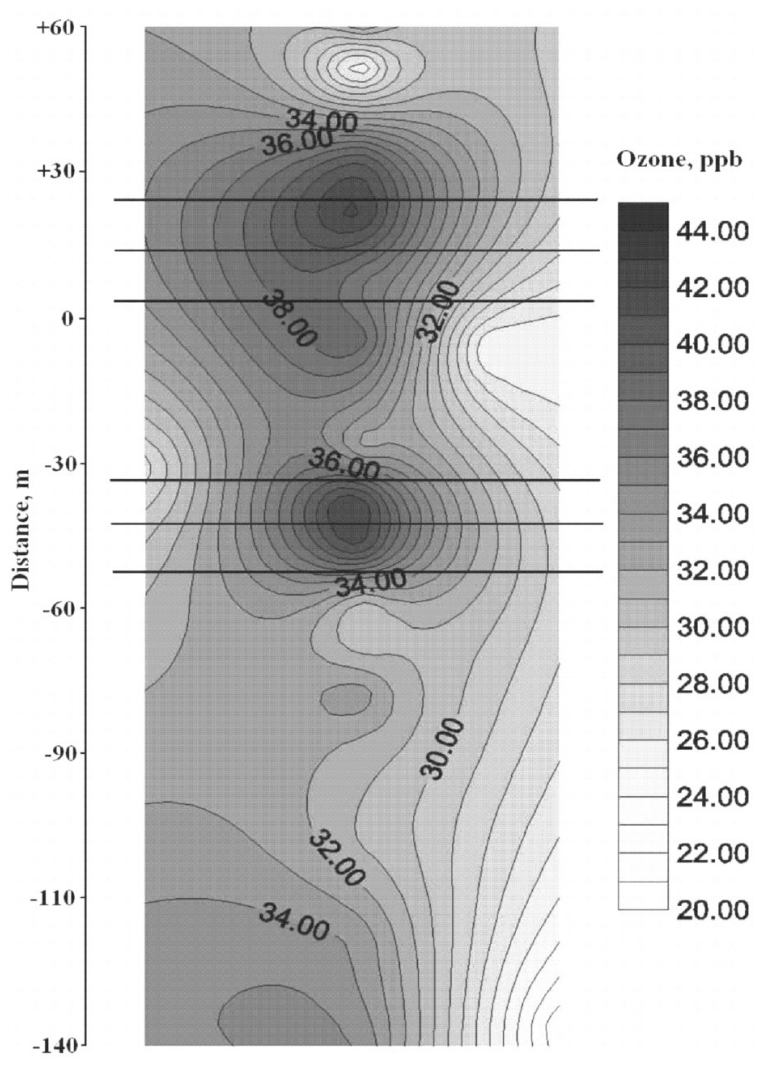

Fig. 6. Ozone concentration change in the vicinity of high-voltage transmission lines.

influence on the ozone level increase at the distance of $220 \mathrm{~m}$ can be observed under conditions favourable for the ozone production near highvoltage lines and its transport to a "background" site.

2. The average ozone concentration close to the high 
voltage lines was on average by $2 \%$ higher than the "background" ozone concentration, and the instantaneous ozone concentration could be higher by up to $38 \%$ in separate cases.

3. The investigation data have shown that meteorological parameters such as the wind speed and direction, relative humidity have the largest influence on the difference between the ozone concentration close to the high-voltage transmission lines and a "background" concentration.

4. The high-voltage transmission lines are not a substantial local source of aerosol particles $(D>$ $0.4 \mu \mathrm{m}$ ) in nonurbanized territories. The change of the air mass transport has the main influence on the aerosol particle concentration variation.

\section{References}

[1] W. Nazaroff, C.J. Weschler, and R.L. Corsi, Indoor air chemistry and physics, Atmos. Environ. 37(39-40), 5451-5453 (2003).

[2] A. Chaloulakou and I. Mavroidis, Comparison of indoor and outdoor concentrations of $\mathrm{CO}$ at a public school. Evaluation of an indoor air quality model, Atmos. Environ. 36(11), 1769-1781 (2002).

[3] A.V. Baughman, Indoor humidity and human health Part I: Literature review of health effects of humidityinfluenced indoor pollutants, ASHRAE Trans. 102(1), 193-211 (1996).

[4] J.D. Spengler, S. Ludwig, and R.A. Weker, Ozone exposures during trans-continental and trans-pacific flights, Indoor Air 14(7), 67-73 (2004) 44 p.

[5] A.S.H. Hamza, Evaluation and measurement of magnetic field exposure over human body near EHV transmission lines, Elec. Power Syst. Res. 74(1), 105-118 (2005).

[6] P. Brown, New evidence power lines cause cancer (2007). Available at: http://www.rense.com/general3/ pwoerlines.htm .

[7] N.F. Elansky, L.V. Panin, and I.B. Belikov, Influence of high-voltage transmission lines on surface ozone concentration, Izvestiya Atmos. Ocean. Phys. 37, Suppl. 1, S92-S101 (2001).

[8] R. Girgždienè, Surface ozone measurement in Lithuania, Atmos. Environ. 25A, 1791-1794 (1991).
[9] J.P. Beck, M. Krzyzanowski, and B. Koffi, Tropospheric Ozone in EU, The consolidated report. EEA Topic report No 8/1998 (European Environment Agency, Copenhagen, 1998).

[10] A. Buffoni, Ozone and nitrogen dioxide measurements in the framework of the National Integrated Programme for the Control of Forest Ecosystems (CONECOFOR), J. Limnol. 61(1), 69-76 (2002).

[11] H.K. Elminir, Dependence of urban air pollutants on meteorology, Sci. Total Environ. 350(1-3), 225-237 (2005).

[12] S.M. Semenow, I.M. Kounina, and B.A. Koukhta, Tropospheric Ozone and Plant Growth in Europe (Publishing Center "Meteorology and Hydrology", Moscow, 1999).

[13] C.H.J. Weschler, Ozone in indoor environments: Concentration and chemistry, Indoor Air 10(4), 269-288 (2000).

[14] N. Blades, T. Oreszczyn, B. Bordass, and M. Cassar, Guidelines on pollution control in museum buildings, Museum Practice (15) (Museums Association, London, 2000).

[15] M. Lippmann, Health effects of ozone. A critical rewiev, J. Air Poll. Contr. Assoc. 39(5), 672-695 (1989).

[16] L. Moldave, S. Kjargaard, T. Sigsgaard, and M. Lebowitz, Interaction between ozone and airborne particulate matter in office air, Indoor Air 15(6), 383-392 (2005).

[17] T. Aalto, J. Hatakka, and Y. Viisanen, Influence of air mass source sector on variation in $\mathrm{CO}_{2}$ mixing ratio at a boreal site in northern Finland, Boreal Environ. Res. 8(4), 385-393 (2003).

[18] B.P. Leaderer, L. Naeher, T. Jankun, K. Balenger, T.R. Holford, C. Toth, J. Sullivan, J.M. Wolfson, and P. Koutrakis, Indoor, outdoor, and regional summer and winter concentrations of $\mathrm{PM}_{10}, \mathrm{PM}_{2.5}, \mathrm{SO}_{4}{ }^{2-}$, $\mathrm{H}^{+}, \mathrm{NO}^{3-}$, and nitrous acid in homes with and without kerosene space heaters, Environ. Health Perspect. 107(3), 223-231 (1999).

[19] EURAD (2008), available at: http://www.eurad.unikoeln.de/index_e.html.

[20] B. Storm, Engineering and Operational Design of the Proposed HVTL and Substations, MP \& GRE Application to the PUC for a HVTL Route Permit: Badoura Transmission Project, Docket ET2, E015/TL-07-76, part 7 (2007). 


\title{
AUKŠTOS IૃTAMPOS ELEKTROS PERDAVIMO LINIJŲ İTAKA TERŠALŲ KONCENTRACIJAI NEURBANIZUOTOSE VIETOVĖSE
}

\author{
V. Valuntaitè, R. Girgždienè \\ Vilniaus Gedimino technikos universitetas, Vilnius, Lietuva
}

\section{Santrauka}

Aptariamas potencialus vietinis oro taršos šaltinis - aukštos itampos elektros perdavimo linijos. Pateikti ozono ir aerozolio dalelių, kaip galimų teršalų prie aukštos itampos linijų, koncentracijos tyrimo rezultatai. Ozono ir aerozolio daleliu $(D>0,4 \mu \mathrm{m})$ skaitinès koncentracijos bei meteorologiniu parametru matavimai atlikti $2007 \mathrm{~m}$. rugsèjo mèn. Utenos rajone prie dvieju $330 \mathrm{kV}$ aukštos ittampos elektros perdavimo linijų. Tuo pačiu metu ozono koncentracija matuota ir $220 \mathrm{~m}$ atstumu nuo linijų, ir ji darbe traktuojama kaip „,foninè“. Vidutinė ozono koncentracija eksperimento metu prie aukštos įtampos linijų buvo didesnè nei foninè. Parodyta, kad prie aukštos įtampos elektros perdavimo linijų tam tikrais atvejais (pvz., nakties metu) stebimas ozono koncentracijos padidejimas iki 38\% palyginus su „fonine“. Aptariama meteorologiniu parametru itaka ozono koncentracijos pokyčiams. Nustatyta, kad oro drègnis, vèjo greitis ir kryptis yra svarbiausi parametrai, salygojantys ozono padidẻjimą aukštos ịtampos linijų aplinkoje neurbanizuotose vietovèse. Aerozolio dalelių ( $D>0,4 \mu \mathrm{m}$ ) skaitinės koncentracijos duomenu analizė parodè, kad aukštos ittampos linijos arba nèra lokalus šiu daleliu šaltinis, arba jo nebuvo galima ìvertinti naudotu metodu. Aerozolio daleliu koncentracijos pokyčius eksperimento metu lèmé oro masių pernašų kaita. 